\title{
Article
}

\section{A relational study of supply chain agility, competitiveness and business performance in the oil and gas industry}

Yusuf, Yahaya, Gunasekaran, Angappa, Musa, Ahmed, Dauda, Mohammed, El-Berishy, Nagham M. and Cang, Shuang

Available at http://clok.uclan.ac.uk/6364/

Yusuf, Yahaya ORCID: 0000-0001-6045-3245, Gunasekaran, Angappa, Musa, Ahmed, Dauda, Mohammed, El-Berishy, Nagham M. and Cang, Shuang (2012) A relational study of supply chain agility, competitiveness and business performance in the oil and gas industry. International Journal of Production Economics, 147 (B). pp. 531-543. ISSN 09255273

It is advisable to refer to the publisher's version if you intend to cite from the work. http://dx.doi.org/10.1016/j.ijpe.2012.10.009

For more information about UCLan's research in this area go to http://www.uclan.ac.uk/researchgroups/ and search for <name of research Group>.

For information about Research generally at UCLan please go to http://www.uclan.ac.uk/research/

All outputs in CLoK are protected by Intellectual Property Rights law, including Copyright law. Copyright, IPR and Moral Rights for the works on this site are retained by the individual authors and/or other copyright owners. Terms and conditions for use of this material are defined in the policies page. 


\title{
A relational study of supply chain agility, competitiveness and business performance in the oil and gas industry
}

\author{
Yahaya Y. Yusuf a,*, Angappa Gunasekaran ${ }^{\mathrm{b}}$, Ahmed Musa ${ }^{\mathrm{a}}$, Mohammed Dauda ${ }^{\mathrm{c}}$, \\ Nagham M. El-Berishy ${ }^{\mathrm{d}}$, Shuang Cang ${ }^{\mathrm{e}}$ \\ ancashire Business School, University of Central Lancashire, Preston, PR1 2HE, UK \\ ${ }^{\mathrm{b}}$ University of Massachusetts-Dartmouth, Dartmouth, NH 03755, USA \\ ${ }^{c}$ Business School, University of Hull, Hull, HU6 7RX, UK \\ ${ }^{\mathrm{d}}$ Production Engineering, University of Bremen, Bremen, Germany \\ e School of Tourism, Bournemouth University, Poole, BH12 5BB, UK
}

\section{A R T I C L E I N F O}

Article history:

Received 3 April 2012

Accepted 13 October 2012

\section{Keywords:}

Supply chain

Oil and gas

Agility

Competitive advantage

Business performance

\begin{abstract}
A B S T R A C T
This paper assesses the link between dimensions of agile supply chain, competitive objectives and business performance in the UK North Sea upstream oil and gas industry. A questionnaire was designed and administered covering important criteria of agility identified from the literature. The questionnaire was sent to a sample of 880 supply chain managers within the UK oil and gas industry and a net response rate of $\mathbf{1 7 . 8 \%}$ was achieved. Statistical tests for validity and reliability were carried out. Also, the KS statistical test for normality was undertaken on the data. All the tests affirm that the data came from a normal distribution. Non-response bias analysis was conducted through wave analysis using one-way ANOVA and no statistically significant difference was revealed by the $t$-test result. By examining the whole supply chain associated with agile practices in an important sector, the paper identifies the most important dimensions and attributes of supply chain agility and provides a deeper insight into those characteristics of agility that are most relevant within the oil and gas industry.
\end{abstract}

Crown Copyright (c) 2012 Published by Elsevier B.V. All rights reserved.

\section{Introduction}

According to the Global Supply Chain Forum, supply chain management seeks to integrate the key business processes, from the original suppliers of raw materials to the end user of the manufactured product. The processes create products, services and information that add value to the stakeholders of the supply chain (Lambert and Cooper, 2000). In tracing the evolution of supply chain management (SCM), Lambert and Cooper (2000), Lamming (1996) and Lamming et al. (2000) observe that the term SCM was introduced by management consultants in the early 1980s and has since generated wide and keen interest across disciplines. Initially, supply chain management was perceived simply as the logistics of manufacturing and distribution, which extends from outside the firm to include customers and suppliers. However, SCM is now conceptualised and applied as the integration of all the business processes across the supply chain. Thus the new model of SCM encompasses all the other business functions, including extended, multi-tiered suppliers and end customers (Pihkala et al., 1999).

\footnotetext{
* Corresponding author.

E-mail address: yyusuf@uclan.ac.uk (Y.Y. Yusuf).
}

The continuously evolving and dynamic nature of the supply chain presents many interesting challenges for effective system coordination. Supply chain members cannot compete as independent members. The product used by the end customer passes through a number of entities that contribute in the value addition of the product before it is consumed. Furthermore, modern traits like globalization, outsourcing and reduction in supply base have exacerbated uncertainty within, and risk exposure of, supply chains. Supply chains have become more prone to sudden disruptions. Systems thinking, which considers both the whole and the constituent parts of ecosystems (Gharajedaghi, 2005; Skyttner, 2006), is providing a new perspective for examining and managing supply chains as both uncut and cut (partial) entities that continuously exchange energies and products.

Recently, Ngai et al. (2012) highlighted the importance of energy saving in production, particularly in textile processing using soft systems methodology. The reported empirical investigations and results in this paper contribute to effective management of oil and gas production and distribution, which in turn will support global energy needs and sustainable resource management.

In trying to understand the circumstances leading to the evolution of SCM, Hill (2000) asserts that companies rarely own the resources and activities to make a product or provide a service 
from the beginning to the end. Indeed, Ramdas and Spekman (2000) contend that, since purchased goods and services account for 50 to $70 \%$ of manufacturing company's potential value, a firm's competitive advantage depends largely on the links it forges with external organisations rather than its internal capabilities. Furthermore, Richardson (1972), and Grandori and Soda (1995) argue, from a transaction cost economics point of view, that the organisation of industry should take cognisance of similarities and complementarities of activities. In addition, Loasby (1998) points to the fact that "all firms depend on the capabilities of their suppliers, and every firm that is not a retailer depends on the capabilities of those who provide it links to the final consumer." In fact some of the activities in the value stream of the product or service delivery system are often not undertaken by the organisation itself, but rather sourced from external vendors. This underpins the need to manage effectively the internal and external phases of the supply chain as an integrated whole.

The oil and gas supply chain, especially the upstream segment, is inherently typified by the above characteristics, with large numbers of small and medium-sized enterprises (SMEs) that provide services and technology to support the operations of the major oil companies. How well these service providers are managed as part of the total supply chain of the major companies is of significant importance to the effectiveness and efficiency of the oil and gas supply chain. Further, the agility of these firms across the oil and gas supply chain and the impact of supply chain performance are of great importance in achieving related supply chain competitiveness.

The survey results reported in this study seek to establish, on the one hand, relationships between the dimensions of agility and related attributes, and, on the other hand, business performance and competitive bases. The paper is divided into four parts. The first part is the literature review that examines issues in supply chain management as well as, in particular, an overview of oil and gas supply chain. The second part discusses the methodology including research questions, sample profile and data collection. The third part presents the results and analysis in an attempt to answer the research questions. The fourth and final section is the conclusions and suggestions for further research.

\section{Literature review}

Supply chain agility has been explored in a number of studies. It has been defined with respect to the agile enterprise (Whitten et al., 2012; Gehani, 1995; Browne et al., 1995; Browne and Zhang, 1999; Jagdev and Browne, 1998; Goranson, 1999), products, workforce (Breu et al., 2002), capabilities (Yusuf et al., 2004), virtual teaming (Bal et al., 1999), and the environment (Robertson and Jones, 1999). The early proponents of agility defined it as a system with exceptional internal capabilities to meet the rapidly changing needs of the market place with speed and flexibility. The internal capacities of the firm include hard and soft technologies, human resources, educated and highly motivated management, and information and communication technologies. A system that shifts quickly (with speed and high responsiveness) among product models or between product lines is said to be flexible. Flexibility often implies responding to customer demand almost in real time (Youssef, 1994).

Goldman et al. (1995) defined agility as a dynamic, context specific, aggressive change that embraces and pursues growth, success, profits, market share and customers. Gehani (1995) and Gligor and Holcomb (2012) contend that an agile organisation can quickly satisfy customer orders, can introduce new products frequently in a timely manner, and can speedily get in and out of strategic alliances with its trading partners. In this case the nimbleness of alliance and partnership formation also constitutes agility, which underscores that the notion of agility is context specific (Goldman et al., 1995; Whitten et al., 2012).

Agility has also been defined in terms of specific activities and operational issues. Kidd (1994) proposed an operational definition of agility as a combination of a number of enterprises such that each has some core skills or competencies that they contribute to a joint business operation. This enables the cooperative enterprises to adapt and respond quickly to changing customer requirements (Kidd, 1994; Yusuf et al., 1999). Kumar and Motwani (1995) defined agility as a firm's ability to progress activities rapidly on the critical path, which is a direct indicator of the firm's capacity to compete on the basis of responsiveness. Thus, agile supply chains use total cycle time-compression as a parameter of competition (Mason-Jones and Towill, 1997, 1999; Mason-Jones et al., 2000). Similarly, agile supply chains may be defined as being about mastering market turbulence (van Hoek, 2000, 2001; van Hoek et al., 2001). This requires specific capabilities, in addition to those that can be achieved by means of lean thinking. A key consideration in this definition is the fact that agility is built on leanness. Thus an organisation needs to become lean by implementing practices that will reduce waste in its operations before it can achieve agility. Thus, leanness and agility are complementary rather than being mutually exclusive. Therefore, leanness and agility can be integrated in practice (Yusuf and Adeleye, 2002; Yusuf et al., 1999, 2003, 2004).

From a manufacturing perspective (Yusuf et al., 1999; Miles and Snow, 1987, 1992), agility can be defined as the successful adoption of competitive bases (speed, flexibility, innovation proactivity, quality and profitability) through the integration of reconfigurable resources and best practices in a knowledge rich environment to provide customer-driven product and services in an uncertain market setting.

The various definitions of agility from some of the key and highly cited works on the subject are summarised in Table 1. Although each of the definitions highlights distinct issues, there are themes that are common to all the definitions. The regular themes can be summarized as customer sensitivity, network integration, process integration, leveraging the impact of people and information. These four principal dimensions of agility will be tested for their impacts on business performance and competitive objectives in the oil and gas clusters.

In the oil and gas supply chain, as in other industries, minor suppliers tend to have limited influence on their supply chains. Wisner (2003) contends that, in most cases, SCM is not feasible in situations such as "when the focal organisation is not in a position of power or structural dominance". It is important therefore for the major operators in the industry to lead the development of SCM. This is increasingly being recognised, as major oil companies for example, believe that agile supply chain rather than internal operations will become the main source of performance improvement. In fact, SCM practices are now seen as offering opportunities to upscale performance when the latitude for cutting internal costs and re-engineering business processes has been exhausted or does not exist (Ernst and Steinhubl, 1997). This follows the trend already set in other sectors (Ramdas and Spekman 2000). In spite of the need for greater SCM practices in the oil and gas industry, evidence suggests that a significant number of oil companies have doubts about the effectiveness of their supply chains and less than half believe they have the requisite tools and skills to optimise their supply chains (Ernst and Steinhubl, 1997). As oil companies move from the practices of retaining all needed capacity in-house to a higher level of outsourcing, greater integration and SCM capability have become profoundly important (Zhou et al., 2010a,b). In our interviews, some industry executives have suggested that up to 
Table 1

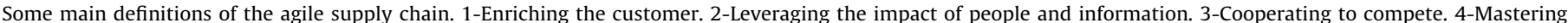
change and uncertainty.

\begin{tabular}{|c|c|c|c|c|c|}
\hline \multirow[t]{2}{*}{ Authors } & \multirow[t]{2}{*}{ Summary definition } & \multicolumn{4}{|c|}{$\begin{array}{l}\text { Dimensions } \\
\text { of agility }\end{array}$} \\
\hline & & 1 & 2 & 3 & 4 \\
\hline Burgess (1994) & Synthesis of diverse technologies and methods of organizing production systems. & & レ & & \\
\hline Kidd (1994) & Agility is being able to provide high quality and highly customised products and services. & 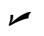 & & & \\
\hline Vastag et al. (1994) & $\begin{array}{l}\text { Intra-enterprise and inter-enterprise integration for flexibility and speed to market, as enabled } \\
\text { by technologies for advanced manufacturing, communication and transportation. }\end{array}$ & & レ & レ & \\
\hline Goldman et al. (1995) & $\begin{array}{l}\text { Agility means delivering products and services with high information content and value-adding } \\
\text { to customers, being ready for change, valuing human knowledge and skills, and virtual } \\
\text { partnership formation. }\end{array}$ & $\boldsymbol{}$ & レ & レ & レ \\
\hline Yusuf et al. (1999) & $\begin{array}{l}\text { Agility is successful exploration of competitive bases through the integration of reconfigurable } \\
\text { resources and best practices in a knowledge-rich environment to provide customer-driven } \\
\text { products and services in a fast changing market environment. }\end{array}$ & $レ$ & レ & & $\boldsymbol{\nu}$ \\
\hline Mason-Jones and Towill $(1997,1999)$ & $\begin{array}{l}\text { Using market knowledge and virtual corporation to exploit profitable opportunities in volatile } \\
\text { business environments. }\end{array}$ & & $\boldsymbol{\nu}$ & レ & $\boldsymbol{V}$ \\
\hline Christopher $(2000,2005)$ & $\begin{array}{l}\text { The ability of an organisation to respond rapidly to changes in demand, both in terms of volume } \\
\text { and variety. }\end{array}$ & レ & & $\boldsymbol{V}$ & レ \\
\hline Harland (1996), Tolone (2000), Gosling et al. (2010) & $\begin{array}{l}\text { Effectively integrating supply chain and forging close and long term relationships with customers } \\
\text { and suppliers. }\end{array}$ & レ & レ & レ & \\
\hline van Hoek et al. (2001) & $\begin{array}{l}\text { Agility is all about customer responsiveness and market turbulence and requires specific } \\
\text { capabilities. }\end{array}$ & レ & $\boldsymbol{V}$ & & $\boldsymbol{V}$ \\
\hline $\begin{array}{l}\text { Aitken et al. (2002), Michael and Wempe (2002), } \\
\text { Swafford et al. (2008), Gosling et al. (2010) }\end{array}$ & $\begin{array}{l}\text { Agility is an ability to have visibility of demand, flexible and quick response and synchronized } \\
\text { operations. }\end{array}$ & 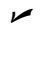 & & レ & レ \\
\hline $\begin{array}{l}\text { Agarwal et al. (2006), Prajogo and Sohal (2006); } \\
\text { Romano (2000), Naim and Gosling (2011), } \\
\text { Kisperska-Moron and de Haan (2011) }\end{array}$ & $\begin{array}{l}\text { Agility implies effective flexibility and quality management to reduce waste and avoid customer } \\
\text { dissatisfaction. It also requires product and service differentiation strategies, as well as the } \\
\text { performance measures of product quality, product innovation and process innovation; all geared } \\
\text { towards flexibility and lead time reduction. }\end{array}$ & レ & レ & & $\boldsymbol{\nu}$ \\
\hline Braunscheidel and Suresh (2009), Mike et al. (2012) & $\begin{array}{l}\text { Agility is a risk management initiative that is needed to provide superior value and to manage } \\
\text { disruption risks and guarantee uninterrupted service provisioning. Agility is required for both } \\
\text { risk mitigation and rapid response. }\end{array}$ & & & & $\boldsymbol{V}$ \\
\hline Jain et al. (2008) & $\begin{array}{l}\text { Agility can be evaluated with both hard and soft criteria of flexibility, profitability, quality, } \\
\text { innovativeness, proactivity, speed of response, cost and robustness. }\end{array}$ & レ & レ & レ & レ \\
\hline
\end{tabular}

$40 \%$ of oil and gas activities will be outsourced from the supply chain over the next five years. This underscores the need for better understanding of the interactions across oil and gas supply chains, the emergent complexity, operations management challenges and the need for greater agility.

As an increasing number of multinational companies in the sector streamline and focus on their core competencies (Prahalad and Hamel 1990), the challenge is to be able to operate as systems integrator (akin to the much publicised case of Boeing in the aerospace industry). This involves managing a complex web of suppliers, service providers, other operating companies, and customers across the value chain. The value chain of the industry encompasses exploration, production, refining, distribution and marketing. Whilst the industry has made some progress in the use of supply chain technologies such as EDI, it remains a laggard in the use of integrated planning and scheduling across the supply chain. The UK oil and gas upstream operations are located within the North Sea. The North Sea remains attractive because of the UK's political, economic and fiscal stability. Porter $(1990,1998,2003)$ attributed much of the competitiveness of countries like the UK to good economic and fiscal environments. However, risks, investment uncertainty, and prospecting and production costs remain one of the highest in the world, even after discounting for cost compression achieved as a result of industry-wide initiatives that sought to reinforce lean practices (CRINE Network, 1999; Swafford et al., 2006a,b, 2008; Abdulmalek and Rajgopal, 2007). A key challenge in the industry today is, therefore, finding organisational solutions to enhance supply chain agility and performance (Spekman, et al., 1998; Ballou et al., 2000; Ramdas and Spekman, 2000; Reichhart and Holweg, 2008; Ramstad et al., 2010; Xia and Tang, 2011; Costantino et al., 2012).

\section{Methodology}

After extensively reviewing the literature on agility, we created, from the literature, a set of agility dimensions as already shown in Table 1. Five industry experts drawn from five oil and gas companies in the Aberdeen area, where most of the upstream oil and gas activities of the UK are located, were then approached for an interview with the aim of better grasping and interpreting the industry perceptions of the dimensions. The summation of their perceptions of each of the dimensions is shown in Table 2. We have labelled these perceptions or industry's interpretations of the dimensions, to reflect earlier work by Yusuf et al. (1999, 2004), as attributes of agility for the oil and gas industry. The aim of this paper was therefore to report a large scale survey by questionnaire conducted to assess the levels of correlation of dimensions and attributes of agility in the oil and gas supply chain with performance and competitive advantages, beyond the five companies used in the preliminary interview-based study.

\subsection{Research questions}

Since late 1990s there have been UK government-supported initiatives to promote lean practices in the oil and gas industry in the UK (CRINE Network, 1999). The need for supply chain responsiveness in the process industry (in general) and the oil and gas sector (in particular) has been recognised. However, unlike in the non-oil sectors, where data abound on the contribution of agility to organisational performance (Yusuf et al., 2004; Lin et al., 2006; Abdulmalek, and Rajgopal, 2007; van der Vaart and van Donk, 2008; Khan and Pillania, 2008; Sarkis et al., 2011; Gunasekaran and Ngai, 2012; Azevedo et al., 2012), the following issues remain unclear in the oil and gas industry: 
Table 2

Principal agility dimensions and their attributes used in the study.

\begin{tabular}{|c|c|c|c|}
\hline Enriching the customer & $\begin{array}{l}\text { Leveraging the impact of people and } \\
\text { information }\end{array}$ & Cooperating to compete & $\begin{array}{l}\text { Mastering change and } \\
\text { uncertainty }\end{array}$ \\
\hline Customer satisfaction focus & Team spirit & Organised along functional lines & Rapid decision making \\
\hline On-time delivery & Team-based performance & Organised along business processes & Encourage risk taking \\
\hline Stock availability focus & Reward based on competencies & Reward based on team performance & Discourage risk taking \\
\hline Customization of products & Involvement in decision making & Reward based on individual performance & Take initiatives \\
\hline $\begin{array}{l}\text { Providing standard } \\
\text { products }\end{array}$ & Managing core competencies & Information available enterprise wide & Encourage innovation \\
\hline Fast delivery of products & Capture demand Information & Information difficult to find & Proactive response to changes \\
\hline Increase customer value & Information is accessible & Matrix project team & $\begin{array}{l}\text { Rapid response to customer } \\
\text { changes }\end{array}$ \\
\hline Customer relationships & Intelligent interpretation of customer needs & Partnering is first choice & \\
\hline Value added products & & Supply chains as networks of associates & \\
\hline \multirow[t]{3}{*}{ Reconfigurable products } & & Supply chains as long-term partners & \\
\hline & & Use cross-functional customer teams & \\
\hline & & $\begin{array}{l}\text { Alliances due to difficult operating } \\
\text { conditions }\end{array}$ & \\
\hline
\end{tabular}

- What dimensions and attributes of agility were most relevant in and for the oil and gas industry?

- What business and performance outcomes are achievable from juxtaposing and scaling agile practices in the oil and gas industry?

In order to achieve a better insight into agility in the oil and gas industry and its impacts on performance, it is important to explore the prevalence of the four principal dimensions of agility and their attributes (see Tables 1 and 2). Therefore, in this paper, as a culmination of the literature review and subsequent interviews in the industry as described in Section 3, we asked the following questions:

1. What is the relationship between the principal dimensions of oil and gas supply chain agility and business performance?

2. What is the relationship between oil and gas supply chain agility attributes and business performance?

3. What is the relationship between the principal dimensions of oil and gas supply chain agility and competitive objectives?

In seeking answers to these three questions, there is a relatively wide array of statistical tools that could be deployed to formulate and test hypotheses. Correlation analysis is the principal tool used in this study because it permits the direct or indirect assessment of the relationships between the research variables. However, correlation on its own does not enable the manipulation of the research variables to allow causal analysis of the relationships between the variables. Indeed, the existence of correlation does not prove causality but, rather, it represents a necessary precondition for causality to be sought: the absence of correlation demonstrates that no causality is present, hence precluding the need for embarking on regression analysis.

\section{Data collection}

A total of eight hundred and eighty (880) questionnaires were mailed out to the addresses of the respondents taken from Financial Analysis Made Easy (FAME) database of companies and other databases that host business directories of corporations. Out of the 880 companies sampled and sent questionnaire, 137 companies completed and returned the survey questionnaire. The response rate was $15.6 \%$. This response rate is considered to be representative of previous similar studies of organisations by questionnaire. In an earlier empirical survey of organisations, Ahmed et al. (1996) achieved a response rate of 6.5\%.
Of the 137 questionnaires returned, 95 were fully completed and were thus deemed valid and usable for the study. Forty-two incomplete questionnaires were excluded from further analysis. Although poorly completed questionnaires still provided some data, researchers often exclude such questionnaires in order to reduce the incidence of missing data in statistical analysis as well as improve the reliability of results (Hair et al., 2006; Tabachnick and Fidell, 2007; Gill and Johnson, 2002). The SPSS statistical package (version 15 for windows) was used to carry out the analysis of the data.

\subsection{Profile of respondents}

Table 3 shows some basic demographic characteristics of the survey respondents, including (i) size of organisations, measured by number of employees, (ii) designation of respondents, (iii) size of organisations by turnover (in millions of pounds), (iv) production process flow, and $(\mathrm{v})$ principal business sectors of the respondents. Examination of Table 3 reveals that the survey is representative in terms of size, production process employed and the designation of the respondents. Additionally, the industries to which the respondents belong, as depicted by their principal business sectors, supports the view that the oil and gas supply chain is served by organisations from diverse industrial sectors.

Among the respondents, heads of organisation (i.e., those with the designation of Managing Director-MD, Chief Executive Officer or Director) constitute the majority, at $57 \%$ of the total number of respondents. Supply chain managers and procurement/purchasing managers each constitute 19\% of the respondents. In this study the most sought after respondents were the CEOs; where the CEOs were indisposed then in their place supply chain managers were used. The viewpoint of the study was that the key information solicited in the study was held by top managers, as they possess better overview of the issues that the study intended to investigate.

Also, it can be observed from the table that about $42 \%$ of the organisations have 50 or fewer employees while about $17 \%$ of the organisations have more than 2000 workers. About $8 \%$ have a workforce in the range of 201 to 500 employees. Thus, the spectrum of the respondents to the survey cut across large companies, as well as small and medium size enterprises (SMEs), but the majority of the respondents to the survey are SMEs or organisations with a number of employees less than 500. This is in line with an earlier study of the oil industry by Cumbers et al. (2003), who found $75 \%$ of respondents to their survey of the Aberdeen oil and gas industry to be SMEs. Further, as the table depicts, the largest category of the firms (about 43\%) are small and medium enterprises with turnovers of less than 10 million 
Table 3

Demographic characteristics of respondents.

\begin{tabular}{|c|c|}
\hline Characteristics & Percentage \\
\hline \multicolumn{2}{|l|}{ Size by number of employees } \\
\hline Up to 50 & 42.1 \\
\hline $51-200$ & 16.8 \\
\hline $201-500$ & 8.5 \\
\hline $501-2000$ & 15.8 \\
\hline Above 2000 & 16.8 \\
\hline \multicolumn{2}{|l|}{ Designation of respondents } \\
\hline MD, CEO, Director & 56.8 \\
\hline Supply chain Manager/Director & 18.9 \\
\hline Procurement/Purchasing Manager & 18.9 \\
\hline Others & 5.3 \\
\hline \multicolumn{2}{|l|}{ Company annual turnover ( $£$ million) } \\
\hline Up to 10 & 43.2 \\
\hline $11-50$ & 16.8 \\
\hline $51-100$ & 6.3 \\
\hline $101-500$ & 15.8 \\
\hline $501-1000$ & 7.4 \\
\hline Above 1000 & 10.5 \\
\hline \multicolumn{2}{|l|}{ Principal business sectors } \\
\hline Exploration and production & 27.4 \\
\hline Consultancy & 6.3 \\
\hline Marine and allied transport services & 2.1 \\
\hline Engineering services and offshore construction & 15.8 \\
\hline Computer and communication equipment & 4.2 \\
\hline Supply and rental of equipment & 1.1 \\
\hline Automotive and automotive accessories & 2.1 \\
\hline Electrical and electronic products & 2.1 \\
\hline Food, drink and chemical and products & 17.9 \\
\hline Industrial, hospital and agricultural products & 4.2 \\
\hline Any other & 16.8 \\
\hline
\end{tabular}

pounds. However, there are large and very large multinational organisations, with turnovers of 500 million and over 1000 million, respectively, that responded to the survey as well.

Organisations in the exploration and production sector are the most represented of all business sectors, at $27 \%$. This is followed by companies operating in food, drink and chemical products, at about $18 \%$. Additionally, organisations involved with engineering services and construction constitutes about $16 \%$. There are also several organisations that are undertaking activities not classified under the business sectors reported in Table 3, thus underscoring the extensively subcontracted nature of the oil and gas business. Oil and gas production draws companies from varied industrial backgrounds to meet its demand for goods and services.

\subsection{Preliminary analysis of data}

Prior to performing inferential statistical analysis, there is the need to assess the characteristics of the distribution of the data to determine whether the variables are normally distributed, as the assumption of normality is a prerequisite for carrying out multivariate analysis. Table 4 shows the results of the KolmogorovSmirnov test statistics with Lilliefors significance level and Sharpiro-Wilk test statistics for normal distribution. The tests relate to the two research variables of location factors and enriching the customer. The tests show that the dataset comes from a normal distribution.

Reliability tests were conducted for the main elements of the research instruments. The test results are reported in Table 5, which shows that the Cronbach's alpha for the overall scale of the survey instrument consisting of 135 variables was found to be 0.849. In addition, the results of this analysis indicate that for all the sub-items of the research instrument the coefficient alphas exceeded 0.70 , and the interrater reliabilities exceeded 0.80 . Thus the scales demonstrate both strong internal consistency and
Table 4

Kolmogorov-Smirnov (KS) tests of normality.

\begin{tabular}{|c|c|c|c|c|c|c|}
\hline & \multicolumn{3}{|c|}{ KS statistics } & \multicolumn{3}{|c|}{ Shapiro-Wilk } \\
\hline & Statistic & $\mathrm{df}$ & Sig. & Statistic & df & Sig. \\
\hline Enriching the customer & .071 & 95 & $.289\left(^{*}\right)$ & .989 & 95 & .619 \\
\hline Industrial Clusters factors & .068 & 95 & $.245\left(^{*}\right)$ & .987 & 95 & .453 \\
\hline
\end{tabular}

Table 5

The reliability of test results.

\begin{tabular}{llc}
\hline Focus of test & $\begin{array}{l}\text { Cronbach's } \\
\text { alpha }\end{array}$ & $\begin{array}{l}\text { Number of } \\
\text { items }\end{array}$ \\
\hline The entire questionnaire & .849 & 135 \\
Demographic characteristics construct & .717 & 6 \\
Agile supply chain dimension construct & .854 & 65 \\
Cluster and location construct & .796 & 27 \\
Distinctive competence construct & .744 & 11 \\
Competitive priorities construct & .727 & 9 \\
Business performance construct & .825 & 5 \\
\hline
\end{tabular}

Table 6

Wave analysis to test external validity for non-response bias of the questionnaire.

\begin{tabular}{llllll}
\hline & $\begin{array}{l}\text { 1st } \\
\text { Wave }\end{array}$ & $\begin{array}{l}\text { 2nd } \\
\text { Wave }\end{array}$ & $\begin{array}{l}\text { 2 tail } \\
\text { sig. }\end{array}$ & df & $\begin{array}{l}\text { Levene's } \\
\text { test }\end{array}$ \\
\hline Turnover & 3.92 & 4.13 & .267 & 93.000 & .387 \\
& & & .266 & 91.546 & \\
Distinctive & 3.85 & 3.94 & .665 & 93.000 & .904 \\
competence & & & .665 & 92.973 & \\
\hline
\end{tabular}

strong interrater reliability. The figure for the reliability of the constructs shown in Table 5 is within the acceptable value of 0.70 . Using results of earlier empirical studies, Swafford et al. (2006a,b) report that while Cronbach's alpha of 0.70 or higher is typically used to establish reliability of a construct, there are situations in which values of 0.6 are acceptable (Forza, 2002), especially for broadly defined constructs like agility attributes.

The results of the wave analysis to test the external validity for potential non-response bias are shown in Table 6 . The first $50 \%$ of the responses received were compared to the last $50 \%$, where the latter were regarded as non-respondents.

It can be seen in Table 6 that, for the demographic characteristics of turnover and distinctive competence, the null hypothesis that there is no significant difference between the mean values of the two waves of responses cannot be rejected. Thus, based on the two tailed significance level and the Levene's $t$-test, as shown in the table, there is no non-response bias.

\section{Results and discussion}

\subsection{Relationship between the principal dimensions of oil and gas supply chain agility and business performance}

In order to examine the relationship between the dimensions of oil and gas supply chain agility and business performance, correlation analysis of the dimensions of agile supply chain attributes and business performance was carried out. In assessing the correlation between agility attributes with business performance, bivariate correlation analysis was performed between the two variables. The result of the analysis (as depicted in Table 7) indicates that only three of the agility attributes correlates with business performance. The agility attributes that posted 
Table 7

Correlations between aggregate agility dimension and business performance.

\begin{tabular}{|c|c|c|c|c|c|}
\hline \multirow[t]{2}{*}{ Attribute } & \multicolumn{5}{|c|}{ Performance measures } \\
\hline & Turnover & Net profit & Market share & Customer loyalty & $\begin{array}{l}\text { Performance relative } \\
\text { to competitors }\end{array}$ \\
\hline Cooperating to compete & $.223^{\mathrm{b}}(.044)$ & ns & & & \\
\hline \multirow[t]{2}{*}{ Mastering change and uncertainty } & $.309^{c}(.005)$ & $.214^{\mathrm{a}}(.054)$ & & & \\
\hline & $.184^{\mathrm{a}}(.098)$ & $.292^{\mathrm{c}}(.008)$ & $.287^{\mathrm{C}}(.009)$ & & \\
\hline Leveraging people and information & $.229^{\mathrm{b}}(.038)$ & $.254^{\mathrm{b}}(.021)$ & $.238^{\mathrm{b}}(.031)$ & $.339^{c}(.002)$ & $.284^{\mathrm{b}}(.010)$ \\
\hline
\end{tabular}

significant relationships with business performance were "cooperating to compete", "mastering change and uncertainty" and "leveraging the impact of people and information". On the other hand, none of the correlations between "enriching the customer" and business performance were significant and so are not reported here.

The result of the analysis reported in Table 7 shows that cooperation posted a significant correlation with turnover only, as all the correlations with the other four performance measures were not significant. On the other hand, leveraging the impact of people and information displayed a positive strong correlation with all the business performance measures, with the strongest correlation of $0.339 p<1 \%$ being with customer loyalty based on repeat orders, followed by "performance relative to competitors". The least significant correlation was with turnover. The next attribute to post remarkable correlation with business performance, after "leveraging the impact of people and information", is "mastering change and uncertainty". As seen in Table 7, "mastering change and uncertainty" also posted a positive significant correlation with all the business performance indices. Unlike "leveraging the impact of people and information", "mastering change and uncertainty" posted a strong positive correlation with the financial business performance of turnover, followed by the market-based performance measures of customer loyalty and performance relative to competitors.

The correlation perspective presented in Table 7 highlights the apparent influence of dimensions of agile supply chains on business performance measures generally. However, specifically it goes to show that agile supply chains have a significant influence on business performance and competitive objectives of the respondents to the study. Moreover, specifically it can be seen that the agility dimension of "cooperating to compete", "mastering change and uncertainty", and "leveraging the impact of people and information" all have positive effect on business performance. On the other hand, customer enrichment posted no significant correlation with any of the business performance measures. Additionally, "leveraging the impact of people and information" posted the highest correlation with customer loyalty; while, with a correlation of about $31 \%$, "mastering change and uncertainty" posted the next highest correlation with turnover. Finally, of the total 11 significant positive correlations between the three agility dimensions and five business performance factors, "mastering change and uncertainty" posted the lowest correlation coefficient with business performance attribute of market share.

The following section assesses in detail correlations between the characteristics of dimensions of agility and five business performance indices. The aim of giving the detailed account of the relationships between the variables is to illustrate and deepen the understanding of the relationship between the two variables at a particular, rather than aggregate, level. This is because the four dimensions of agility (such as enriching the customer etc.) will offer little in the form of guidance to practitioners and managers that are interested in attainment of agility in their supply chain and its attendant influence on competitiveness and business performance. In other words, if organisations are interested in enhancing financial or marketing growth, what specific variable of the agility dimension do they need to focus on? The analysis given in the following section will attempt to answer the preceding question by highlighting the relationships between the variables of the four dimensions of agility and business performance.

\subsection{Assessing the relationship between the attributes of dimensions of agility and business performance}

In a dynamic business environment in which non-price-based competition dominates, competitive basis tends to change from cost-based factors to attribute-based factors such as quality advantages and factors that enhance customer satisfaction. Thus, for those types of market situations, an organisation focuses on quality and enriching the customer in an effort to create more value for the customer enhances its competitiveness. Creating customer value is one of the dimensions of agile supply chains, and a correlation analysis was carried out to determine the impact of creating customer value on business performance.

The correlation coefficients between business performance and the agility dimension of "enriching the customer" are presented in Table 8 . In the questionnaire, there were 19 variables that were used to elicit perception about the attributes of agility. From Table 8 it can be seen that among the attributes of enriching the customer, 10 out of the 19 variables have a significant correlation with aspects of business performance. Of the 10 attributes that are significantly correlated to business performance, the highest correlation of about $34 \%$ is recorded between reconfigurable products and market share. This means that organisations that possess the ability to deliver reconfigurable products could have an increased market share through gaining a share of the competitors' market. Equally and expectedly, ability to provide reconfigurable products has a significant correlation with customer loyalty based on repeat orders and performance relative to competitors. Thus, this result indicates that being able to provide reconfigurable products correlates significantly with the non-financial performance measures rather than financial measures of net profit or turnover. This indicates that ability to provide reconfigurable products leads to enhanced competitiveness rather than financial performance. Similarly, of the 14 variables used to measure the customer enrichment dimension of agile supply chain, the 10 variables that recorded significant correlation to business performance are: having a customersatisfaction focus, on-time delivery, stock availability focus, customization of products, providing standard products, fast delivery of products, increased customer value, value-added products and reconfigurable products. 
Table 8

Correlation coefficients of enriching the customer with business performance.

\begin{tabular}{|c|c|c|c|c|c|}
\hline \multirow[t]{2}{*}{ Attribute } & \multicolumn{5}{|l|}{ Performance } \\
\hline & Turnover & Net profit & Market share & Customer loyalty & $\begin{array}{l}\text { Performance relative } \\
\text { to competitors }\end{array}$ \\
\hline Customer satisfaction focus & ns & & & $.266^{\mathrm{c}}(.009)$ & ns \\
\hline On-time delivery & $.211(.057)^{\mathrm{a}}$ & ns & $.242(.028)^{\mathrm{b}}$ & $.222(.045)^{\mathrm{b}}$ & $.251(.023)^{\mathrm{b}}$ \\
\hline Stock availability focus & ns & ns & $.198(.075)^{\mathrm{a}}$ & ns & ns \\
\hline Customization of products & ns & $.207(.062) \mathrm{a}$ & $.203(.067)^{\mathrm{a}}$ & ns & $.191(.086)^{\mathrm{a}}$ \\
\hline Providing standard products & ns & $.232(.036)^{\mathrm{b}}$ & $.222(.045)^{\mathrm{b}}$ & ns & \\
\hline Fast delivery of products & ns & & $.272(.013)^{\mathrm{b}}$ & ns & \\
\hline Increase customer value & ns & & & $.217(.050)^{\mathrm{a}}$ & ns \\
\hline Customer relationships & ns & $.201(.070)^{\mathrm{a}}$ & ns & $.190(.087)^{\mathrm{a}}$ & $.230(.038)^{\mathrm{b}}$ \\
\hline Value added products & & $.205(.064)^{\mathrm{a}}$ & ns & & \\
\hline Reconfigurable products & $.207(.062)^{\mathrm{a}}$ & ns & $.337(.002)^{\mathrm{c}}$ & $.285(.009)^{\mathrm{c}}$ & $.314(.004)^{\mathrm{c}}$ \\
\hline
\end{tabular}

Table 9

Leveraging the impact of people and information with business performance.

\begin{tabular}{|c|c|c|c|c|c|}
\hline \multirow[t]{2}{*}{ Attribute } & \multicolumn{5}{|l|}{ Performance } \\
\hline & Turnover & Net profit & Market share & Customer loyalty & $\begin{array}{l}\text { Performance relative } \\
\text { to competitors }\end{array}$ \\
\hline Team spirit & ns & & & $.258^{\mathrm{b}}(.019)$ & $.245^{\mathrm{b}}(.027)$ \\
\hline Team-based performance & ns & & & $.255^{\mathrm{b}}(.021)$ & $.275^{\mathrm{b}}(.012)$ \\
\hline Reward based on competencies & ns & & & $.190^{\mathrm{a}}(.087)$ & $.223^{\mathrm{b}}(044)$ \\
\hline Involvement in decision making & ns & & & $.278(.011)^{\mathrm{b}}$ & $.301^{\mathrm{c}}(.006)$ \\
\hline Managing core competencies & ns & & & & $.228^{\mathrm{b}}(.039)$ \\
\hline Capture demand Information & $.323^{\mathrm{c}}(.003)$ & $.377^{\mathrm{c}}(.000)$ & $.328^{\mathrm{c}}(.003)$ & $.324^{\mathrm{c}}(.003)$ & $.411^{\mathrm{c}}(.000)$ \\
\hline Information is accessible & ns & & & & $.275^{\mathrm{b}}(.012)$ \\
\hline Intelligent interpretation of customer needs & ns & $.218^{\mathrm{b}}(.049)$ & ns & $.258^{\mathrm{b}}(.019)$ & $.269^{\mathrm{b}}(.015)$ \\
\hline
\end{tabular}

Significance at

a $10 \%$ level indicated.

b $5 \%$ level indicated.

c $1 \%$ level indicated.

It is instructive that both "customization of products" and "providing standard products" were significantly correlated to customer enrichment. This is due to the fact that customization and standardisation of products are contending variables in the customer enrichment dimension of agility. This means that organisations could be competing on the mass production paradigm, whereby they would want to provide standard products with cost being the competitive focus; or organisations could adopt customer enrichment through the provision of mass customisation of products or service in line with customer needs aimed at attaining higher customer satisfaction. Thus, in the case of mass customisation, attaining customer satisfaction is the competitive objective. This result, in which both the contending competitive objectives are at play, point to the diversity of competitive objectives of members of the oil and gas supply chain. In this industry, some firms supply standard products while others supply more customised products and services. A study of the organisational arrangement of the UK oil and gas industry by Finch (2002) found that the industry places "emphasis on rent-seeking contracting rather than valuecreating activities", such that oil operators seek "commodities rather than specialised and bespoke solutions from services providers" (Finch, 2002). Accordingly, there are industry initiatives targeted at standardisation of processes and technologies. Thus, initiatives have been launched for standard well designs, drilling solutions, contracts, and assessments of components suppliers and service providers (Finch, 2002).
Table 9 shows the correlation coefficients and relationships between "leveraging the impact of people and information" and business performance. From the table it is apparent that of the 40 correlations between the variables, 18 of the variables have significant positive correlations between "leveraging the impact of people and information" and business performance. Of the variables that correlated with business performance, "capture demand information" recorded positive significant correlations with all the variables of business performance. The correlations between "capture demand information" and performance relative to competitors, net profit, market share, customer loyalty, and turnover are $0.411,0.377,0.328,0.324$ and 0.323 , respectively. Additionally, of all the business performance variables, performance relative to competitors recorded significant positive correlations with all the variables of the agility attribute of "leveraging the impact of people and information".

Tables 10 and 11 reports the correlations between cooperating to compete and business performance. The strongest significant correlation of about $42 \%$ was recorded between turnover and the attribute "organised along functions and department". The next highest correlation for turnover was recorded with "rewards based on individual performance", at 0.246 . Furthermore, alliances and supply chains as network associates were all perceived to have influence on turnover. On the other hand, net profit correlates only with organised along functional lines, at.198. The result of the relationships between financial business performance and agility dimension of "cooperating to compete" posted 
Table 10

Correlations of "cooperating to compete" and business performance.

\begin{tabular}{|c|c|c|c|c|c|}
\hline \multirow[t]{2}{*}{ Attribute } & \multicolumn{5}{|l|}{ Performance } \\
\hline & Turnover & Net profit & Market share & Customer loyalty & $\begin{array}{l}\text { Performance relative } \\
\text { to competitors }\end{array}$ \\
\hline Organised along functional lines & $.415^{\mathrm{c}}(000)$ & $.198(.075)^{\mathrm{a}}$ & & & $.199(.073)^{\mathrm{a}}$ \\
\hline Organised along business processes & & & & $.186(.094)^{\mathrm{a}}$ & \\
\hline Reward based on team performance & & & & $.222(.045)^{\mathrm{b}}$ & $.254(.022)^{\mathrm{b}}$ \\
\hline Reward based on individual performance & $.246(.026)^{\mathrm{b}}$ & & $.280(.011)^{\mathrm{b}}$ & & \\
\hline Information available enterprise wide & & & & & $.272^{\mathrm{b}}(.013)$ \\
\hline Information difficult to find & & & & & $-.192(.084)^{\mathrm{a}}$ \\
\hline Matrix project team & & & $.209^{\mathrm{a}}(.060)$ & & $.270(.014)^{\mathrm{b}}$ \\
\hline Partnering is first choice & & & & $.255(.021)^{\mathrm{b}}$ & $.206(.063)^{\mathrm{a}}$ \\
\hline Supply chains as network associates & $.215(.052)^{\mathrm{a}}$ & & $.193(.082)$ & & \\
\hline Supply chains as long-term partners & & & & $.389^{\mathrm{c}}(.000)$ & \\
\hline Use cross-functional customer teams & & & $.315^{\mathrm{c}}(.004)$ & $.317^{\mathrm{c}}(.004)$ & $.276(.012)^{\mathrm{b}}$ \\
\hline Alliances due to difficult operating conditions & $.226(.041)^{\mathrm{b}}$ & $.183(\mathrm{~ns})$ & $.274(.013)^{\mathrm{b}}$ & & $.187(.092)^{\mathrm{a}}$ \\
\hline
\end{tabular}

Significance at

a $10 \%$ level indicated.

b $5 \%$ level indicated.

c $1 \%$ level indicated.

Table 11

Correlations of "mastering change and uncertainty" with business performance.

\begin{tabular}{|c|c|c|c|c|c|}
\hline \multirow[t]{2}{*}{ Attribute } & \multicolumn{5}{|l|}{ Performance } \\
\hline & Turnover & Net profit & Market Share & Customer loyalty & $\begin{array}{l}\text { Performance relative } \\
\text { to competitors }\end{array}$ \\
\hline Rapid decision making & & & & $.212^{\mathrm{a}}(.039)$ & $.279^{\mathrm{b}}(.006)$ \\
\hline Encourage risk taking & & & $.318^{\mathrm{a}}(.002)$ & $.285^{\mathrm{b}}(.005)$ & $.414^{\mathrm{b}}(.000)$ \\
\hline Discourage risk taking & & & $-.295^{\mathrm{b}}(.004)$ & $.225^{\mathrm{a}}(.029)$ & $-.305^{\mathrm{b}}(.003)$ \\
\hline Take initiatives & & & & & $.204^{\mathrm{a}}(.048)$ \\
\hline Encourage innovation & $.331^{\mathrm{b}}(.001)$ & $.315^{\mathrm{b}}(.002)$ & $.287^{\mathrm{b}}(.005)$ & $.314^{\mathrm{b}}(.002)$ & $.320^{\mathrm{b}}(.002)$ \\
\hline Proactive response to changes & & & $.226^{\mathrm{a}}(.028)$ & $.255^{\mathrm{a}}(.013)$ & $.273^{\mathrm{b}}(.007)$ \\
\hline Rapid response to customer changes & $.227^{\mathrm{a}}(.027)$ & & & & $.255^{\mathrm{a}}(.013)$ \\
\hline
\end{tabular}

Significance at

a $10 \%$ level indicated.

b $5 \%$ level indicated.

a lower level of correlation than that between market-based nonfinancial indices. This is in line with the general perception that cooperative relationships within and across organisations take time to mature and need nurturing. For example, it is seen in Table 10 that considering and engaging supply chains as longterm partnerships does lead to enhanced customer loyalty. This could be due to the fact that more time is dedicated to creating the right product to meet the customer requirement such that customer satisfaction is achieved in the product or service. This customer satisfaction then translates into repeat orders. This discovery corroborates an earlier finding by Swafford et al. (2006b) who found that supplier relations enable improved responsiveness and customer satisfaction.

Also, using cross-customer teams leads to enhancing all the marketing performance indices of market share, customer loyalty and performance relative to competitors. This supports the hypothesis that acquiring the agility attribute of "cooperating to compete" enhances business performance.

\subsection{Assessing relationship between the principal dimensions of agility and competitive objectives}

In assessing the relationship between the dimensions of agility and competitive objectives a bivariate correlation analysis between the main dimensions of agility and competitive objectives was carried out. The results of the bivariate correlation analysis between the two variables are presented in six tables (Tables 12 to 17). These show only the result of significant correlation coefficients at the 10,5 and 1\% levels of significance between the two variables. The data shown in the six tables can be summarised as follows.

Table 12 shows the result of the correlations between the principal dimensions of agility and the competitive objectives, while Tables 13-17 (see appendix) give a detailed analysis of correlations of the characteristics of each of the principal dimensions of agility, given in Table 2, and their corresponding correlations with individual competitive objectives.

Table 13 shows that all the four dimensions of agility registered some level of positive significant correlation with all the competitive objectives except customisation. This means that the surveyed organisations do not perceive customisation as a competitive tool that will enable them to outperform their rivals. This finding is ironic in that the UK oil and gas industry has been perceived as an industry that requires a high level of innovation, especially due to the need to produce from the deep offshore fields (Bower and Young, 1995; Crabtree et al., 1997, 2000; Cumbers et al., 2003; Cumbers and MacKinnon, 2004; Mackinnon et al., 2004). Clearly, the findings from this research point to less incidence of customisation within the industry, to such an extent that the ability to deliver customised products is not perceived as a competitive advantage. Indeed, in Table 13 it can be seen that the result of correlation coefficient between 
Table 12

Correlation coefficients between agility dimensions and competitive objectives.

\begin{tabular}{|c|c|c|c|c|}
\hline \multirow[t]{2}{*}{ Attribute } & \multicolumn{4}{|l|}{ Dimension } \\
\hline & Customer enrichment & Cooperation & $\begin{array}{l}\text { Mastering change } \\
\text { and uncertainty }\end{array}$ & $\begin{array}{l}\text { Leveraging impact of } \\
\text { people and information }\end{array}$ \\
\hline Delivery & $.289^{\mathrm{c}}(.009)$ & $.211^{\mathrm{a}}(.057)$ & $.270^{\mathrm{b}}(.014)$ & \\
\hline Proactivity & $.233^{\mathrm{b}}(.044)$ & $.279^{\mathrm{b}}(.011)$ & $.289^{\mathrm{c}}(.008)$ & $.239^{\mathrm{b}}(.030)$ \\
\hline Dependability & $.291^{\mathrm{c}}(.008)$ & & $.184^{\mathrm{a}}(.098)$ & \\
\hline Quality & & $.284^{\mathrm{a}}(.040)$ & $.321^{\mathrm{c}}(.003)$ & $.233^{\mathrm{b}}(.035)$ \\
\hline Flexibility & $.230^{\mathrm{b}}(.038)$ & & & \\
\hline Cost & $.203^{\mathrm{a}}(.067)$ & & & \\
\hline Innovation & & $.262^{\mathrm{b}}(.017)$ & $.487^{\mathrm{c}}(.000)$ & $.433^{\mathrm{c}}(.000)$ \\
\hline Speed & $.234^{\mathrm{b}}(.034)$ & $.269^{\mathrm{b}}(.015)$ & $.439^{\mathrm{c}}(.000)$ & $.356^{\mathrm{c}}(.001)$ \\
\hline
\end{tabular}

Table 13

Correlations between the agility dimension of customer value and competitive objectives.

\begin{tabular}{|c|c|c|c|c|c|c|c|c|c|}
\hline & Customisation & Flexibility & Cost & Speed & Innovation & Quality & Dependability & Proactivity & Delivery \\
\hline Customer satisfaction focus & & $.206^{\mathrm{a}}(.063)$ & & $.201^{\mathrm{a}}(.070)$ & & & $.352^{\mathrm{c}}(.001)$ & $.233^{\mathrm{b}}(.035)$ & $.254^{\mathrm{b}}(.021)$ \\
\hline Measure customer satisfaction & & & & & & $.194^{\mathrm{a}}(.081)$ & $.229^{\mathrm{b}}(.039)$ & & \\
\hline On-time delivery & & & & & $.204^{\mathrm{a}}(.066)$ & & $.346^{\mathrm{c}}(.001)$ & & $.376^{\mathrm{c}}(.001)$ \\
\hline Flexible to customer needs & & $.399^{\mathrm{c}}(.000)$ & $.305^{\mathrm{c}}(.005)$ & $.383^{\mathrm{c}}(.000)$ & & & $.245^{\mathrm{b}}(.026)$ & & $.247^{\mathrm{b}}(.025)$ \\
\hline Providing standard products & $-.303^{\mathrm{c}}(.002)$ & & & & & & & & \\
\hline Customer driven products & $.297^{\mathrm{c}}(.007)$ & $.369^{\mathrm{c}}(.001)$ & $.213^{\mathrm{a}}(.055)$ & $.232^{\mathrm{b}}(.036)$ & & $.275^{\mathrm{b}}(.012)$ & & & \\
\hline Fast delivery of products & & $.257^{\mathrm{b}}(.020)$ & & $.208^{\mathrm{a}}(.060)$ & $.217^{\mathrm{b}}(.050)$ & & & & \\
\hline Increase customer value & & $.188^{\mathrm{a}}(.092)$ & $.191^{\mathrm{a}}(.086)$ & $.385^{\mathrm{c}}(.000)$ & $.318^{\mathrm{c}}(.004)$ & $.341^{\mathrm{c}}(.002)$ & $.290^{\mathrm{c}}(.008)$ & $.247^{\mathrm{b}}(.025)$ & $.255^{\mathrm{b}}(.021)$ \\
\hline Customer relationships & & $.185^{\mathrm{a}}(.096)$ & & $.315^{\mathrm{c}}(.004)$ & $.185^{\mathrm{a}}(.096)$ & $.197^{\mathrm{a}}(.076)$ & $.222^{\mathrm{b}}(.045)$ & $.327^{\mathrm{c}}(.003)$ & $.223^{\mathrm{b}}(.044)$ \\
\hline Value-added products & & & & & & $.241^{\mathrm{b}}(.029)$ & & $.205^{\mathrm{a}}(.065)$ & \\
\hline
\end{tabular}

Significance at

a $10 \%$ level indicated.

b $5 \%$ level indicated.

c $1 \%$ level indicated.

customisation and providing standard products is significant but negative correlation. This means that where the need for standard products is high, there is low level of customisation and vice versa. This goes to show that there is a high preference for standard products within the industry rather than customised products. This finding is in line with the current drive within the industry for cost reduction, in which product standardisation is encouraged by using standard products to build modules for oil and gas production platforms (CRINE Network, 1999).

Customer enrichment posted the highest significant positive correlation with dependability and delivery, followed by proactivity and flexibility. Cooperating to compete correlates positively with quality, proactivity and speed. "Mastering change and uncertainty" posted the highest correlation with innovation and speed, followed by quality and proactivity. Finally, "leveraging the impact of people and information" posted significant positive correlations with innovation and speed, followed by quality and proactivity. Among the four dimensions of agility, "mastering change and uncertainty" posted the highest correlation, followed by "leveraging the impact of people and information."

From Table 12, it is apparent that an organisation that masters change and uncertainty can derive the competitive advantage of innovation, competing on time through speed as well as being proactive. That organisation is considered to have delivery reliability as well as competing without compromising on quality. Moreover, the organisations surveyed in this study considered a significant level of dependability as a competitive advantage.

Tables 12 and 13 present a detailed analysis of the relationships between two of the dimensions of agility and the competitive objectives. This is aimed at identifying the factor within each of the agility dimensions that has the most impact on the speed and flexibility. As shown in Table 12, enriching the customer by adding value posted significant correlations with the following competitive objectives: speed, quality, innovation, dependability, delivery reliability and proactivity.

The correlation coefficients indicate significant positive correlations between the competitive objective of speed and the agility dimension of enriching the customer. This shows that ability to compete on speed is contingent on customer relationships, as the positive correlation coefficient between speed and customer relationship focus shows.

Table 14 shows the correlations between the agility dimension of "leveraging the impact of people and information" with competitive objectives. The main conclusion to draw from that table is that all the competitive objectives posted significant positive correlations with most of the variables of the agility dimension of "leveraging the impact of people and information". In particular, it is interesting that ability to capture demand information quickly enhances speed of response. Furthermore, the two variables of ability to capture demand and managing core competencies correlate positively with all the competitive objectives. Equally, training enhances delivery, proactivity, cost reduction and flexibility.

\section{Conclusions}

It has been observed in this study that, increasingly, competitive advantage is currently predicated on the combined 
Table 14

Correlation between the agility dimension of "leveraging the impact of people and information" and competitive objectives.

\begin{tabular}{|c|c|c|c|c|c|c|c|c|}
\hline & Flexibility & Cost & Speed & Innovation & Quality & Dependability & Proactivity & Delivery \\
\hline Autonomy & & & & & & $.234^{\mathrm{b}}(.035)$ & & \\
\hline Team spirit & $.201^{\mathrm{a}}(.071)$ & $.195^{\mathrm{a}}(.079)$ & $.208)^{\mathrm{a}}(.061$ & & $.231^{\mathrm{b}}(.037)$ & $.261^{\mathrm{b}}(.018)$ & & \\
\hline Team-based performance & $.288^{\mathrm{c}}(.009)$ & $.269^{\mathrm{b}}(.015)$ & $.276^{\mathrm{b}}(.012)$ & & & $.193^{\mathrm{a}}(.083)$ & $.266^{\mathrm{b}}(.016)$ & \\
\hline Individual performance & & $.207^{\mathrm{a}}(.062)$ & & & $.187^{\mathrm{a}}(.097)$ & & $.226^{\mathrm{b}}(.041)$ & $.194^{\mathrm{a}}(.080)$ \\
\hline Reward based on competencies & & & & & & $.235^{\mathrm{b}}(.022)$ & $.237^{\mathrm{b}}(.032)$ & $.287^{\mathrm{c}}(.009)$ \\
\hline Involvement in decision making & & & $.231^{\mathrm{a}}(.055)$ & $.271^{\mathrm{b}}(.014)$ & $.245^{\mathrm{b}}(.026)$ & $.209^{\mathrm{a}}(.060)$ & $.183^{\mathrm{a}}(.100)$ & $.225^{\mathrm{b}}(.043)$ \\
\hline Training & $.256^{\mathrm{b}}(.020)$ & $.360^{\mathrm{c}}(.001)$ & $.194^{\mathrm{a}}(.081)$ & & $.262^{\mathrm{b}}(.017)$ & $.287^{\mathrm{C}}(.009)$ & $.350^{\mathrm{c}}(.001)$ & $.376^{\mathrm{c}}(.000)$ \\
\hline Managing core competencies & $.255^{\mathrm{b}}(.021)$ & $.216^{\mathrm{a}}(.052)$ & $.253^{\mathrm{b}}(.022)$ & $.285^{\mathrm{c}}(.009)$ & $.203^{\mathrm{a}}(.067)$ & $.201^{\mathrm{a}}(.070)$ & $.397^{\mathrm{c}}(.000)$ & $.327^{\mathrm{c}}(.003)$ \\
\hline Capture demand & $.312^{\mathrm{c}}(.004)$ & $.246^{\mathrm{b}}(.026)$ & $.443^{\mathrm{c}}(.000)$ & $.195^{\mathrm{a}}(.080)$ & $.290^{\mathrm{c}}(.008)$ & $.248^{\mathrm{b}}(.025)$ & $.326^{\mathrm{c}}(.003)$ & $.378^{\mathrm{c}}(.000)$ \\
\hline Information accessible & & & & $.195^{\mathrm{a}}(.079)$ & $.227^{\mathrm{b}}(.040)$ & & & \\
\hline Intelligent interpretation of customer needs & & $.201^{\mathrm{a}}(.069)$ & $.207^{\mathrm{a}}(.062)$ & $.428^{\mathrm{c}}(.000)$ & $.217^{\mathrm{a}}(.050)$ & $.255^{\mathrm{b}}(.021)$ & $.274^{\mathrm{b}}(.013)$ & $.380^{\mathrm{c}}(.000)$ \\
\hline
\end{tabular}

Significance at

a $10 \%$ level indicated.

b $5 \%$ level indicated.

c $1 \%$ level indicated.

Table 15

Correlation coefficients between the agility dimension of "mastering change and uncertainty" and competitive objectives.

\begin{tabular}{|c|c|c|c|c|c|c|c|c|c|}
\hline & Customisation & Flexibility & Cost & Speed & Innovation & Quality & Dependability & Proactivity & Delivery \\
\hline $\begin{array}{l}\text { Concurrency for rapid } \\
\text { decision making }\end{array}$ & & & & $.279^{\mathrm{c}}(.006)$ & & & $.230^{\mathrm{b}}(.025)$ & & \\
\hline Encourage risk taking & & & & & $.245^{\mathrm{b}}(.027)$ & & $.292^{\mathrm{c}}(.004)$ & $.268^{\mathrm{b}}(.015)$ & \\
\hline Discourage risk taking & & & & & $-.222(.045)^{\mathrm{b}}$ & & $-.236^{\mathrm{b}}(.022)$ & $-.290^{\mathrm{c}}(.008)$ & \\
\hline Take initiatives & & $.248^{\mathrm{b}}(.025)$ & $.364^{\mathrm{c}}(.001)$ & $.296^{\mathrm{c}}(.007)$ & & & $.276^{\mathrm{C}}(.009)$ & & $.232^{\mathrm{b}}(.024)$ \\
\hline Encourage innovation & & $.375^{\mathrm{c}}(.001)$ & & $.457^{\mathrm{c}}(.000)$ & $.662^{\mathrm{c}}(.000)$ & $.304(.005)^{\mathrm{c}}$ & $.201 *(.071)$ & $.389^{\mathrm{c}}(.000)$ & $.262^{\mathrm{b}}(.017)$ \\
\hline Proactive response & & $.250^{\mathrm{b}}(.024)$ & $.209^{\mathrm{a}}(.059)$ & $.231^{\mathrm{b}}(.037)$ & $.355^{\mathrm{c}}(.001)$ & & & $.345^{\mathrm{c}}(.001)$ & $.280^{\mathrm{b}}(.011)$ \\
\hline New supplier process & & $.206^{\mathrm{a}}(.063)$ & $.207^{\mathrm{a}}(.062)$ & $.382^{\mathrm{C}}(.000)$ & $.280^{\mathrm{b}}(.011)$ & $.290(.008)^{c}$ & $.268^{\mathrm{b}}(.015)$ & $.216^{\mathrm{a}}(.051)$ & $.301^{\mathrm{c}}(.006)$ \\
\hline $\begin{array}{l}\text { Organisational boundaries } \\
\text { do not existent }\end{array}$ & & & & & $.245^{\mathrm{b}}(.026)$ & & & & \\
\hline $\begin{array}{l}\text { Rapid response to } \\
\text { customer changes }\end{array}$ & $.342^{\mathrm{c}}(.002)$ & $.261^{\mathrm{b}}(.018)$ & & & $.301^{\mathrm{c}}(.006)$ & $.297(.007)^{\mathrm{c}}$ & & & \\
\hline $\begin{array}{l}\text { Productivity and quality } \\
\text { measures of operations }\end{array}$ & & $.334^{\mathrm{c}}(.002)$ & & & & $.311(.004)^{\mathrm{c}}$ & $.253^{\mathrm{b}}(.022)$ & & $.212(.056)^{\mathrm{a}}$ \\
\hline $\begin{array}{l}\text { Broad-based measures } \\
\text { of capability used }\end{array}$ & & & & & $.207^{\mathrm{a}}(.062)$ & $.203^{\mathrm{a}}(.067)$ & $.239^{\mathrm{b}}(.031)$ & $.249^{\mathrm{b}}(.024)$ & $.241^{\mathrm{b}}(.029)$ \\
\hline
\end{tabular}

Significance at

a $10 \%$ level indicated.

b $5 \%$ level indicated.

c $1 \%$ level indicated.

capabilities of the integrated network of organizations, i.e., on the supply chain. It is argued that understanding the dynamics of competition amongst supply chains is more important to the individual firm than analysing contests between firms. Additionally, markets nowadays exhibit obvious traits of increasing complexity and volatility and decreasing predictability. Hence, today the need to leverage the capabilities of the whole supply chain to satisfy customer demand is ever present and is greater than previously. Characteristic turbulence in the business environment leads to the need for agile supply chains. But the strategy for competing on the basis of agility is a managerial imperative not only for the individual constituents of the chain but for the entire supply chain. Flexible and agile supply chains outperform less agile competitors. This paper has demonstrated that contrary to perception in some sections of the literature, much volatility does exist in the oil and gas industry. Oil and gas are often classified as commodities; as such it has been claimed in some literatures that their supply chains should focus on cost. However, this classification looks only at the final product (at the point of consumption), and neglects the range of complex activities associated with exploration, development and production of hydrocarbons. The production of crude oil is an example of heavy industrial activity, in which the extraction method is complex and constrained by critical delivery date, cost and quality. High levels of complexity and uncertainty are typical of the environment in which hydrocarbons are sought and extracted.

We assert that agility is very much determined by the operating environment and the business sector or industry of the given supply chain. Most of previous works on agility have been in discrete manufacturing. There has been a conspicuous lack of results on agility in the process industry. This paper does, therefore, contributes to filling the gap. By assessing the spread and depth of agile practices within the oil and gas supply chain, this paper has provided new oil and gas industry-focused insights into agility. Specifically, this comprehensive study reveals the empirical relations between dimensions of agility and the attainment of competitive objectives and business performance. The results from this study suggest a direct-effect model in which the dimensions of supply chain agility (i.e., customer enrichment, cooperating to compete, mastering change, and leveraging the impact of people and information) moderate competitive objectives and business performance. Thus, the paper has explicitly demonstrated that agility has a significant influence on competitive objectives and business performance of the sample firms used in this study.

The aggregate effects of dimensions of agility indicate that whereas "cooperating to compete" impacts only turnover, "mastering change" and "leveraging impact of people" correlates with 
Table 16

Correlations coefficient between the agility dimension of "cooperating to enhance competitiveness" and competitive objectives.

\begin{tabular}{|c|c|c|c|c|c|c|c|c|c|}
\hline & Customisation & Flexibility & Cost & Speed & Innovation & Quality & Dependability & Proactivity & Delivery \\
\hline $\begin{array}{l}\text { Organised along functions } \\
\text { and departments }\end{array}$ & & & & $.255^{\mathrm{b}}(.021)$ & & & & & \\
\hline $\begin{array}{l}\text { Organised along } \\
\text { business processes }\end{array}$ & & & & & $.255^{\mathrm{b}}(.012)$ & & & $.209^{\mathrm{b}}(.042)$ & \\
\hline $\begin{array}{l}\text { Reward based on } \\
\text { team performance }\end{array}$ & & $.310^{c}(.005)$ & & & & & & $.195^{\mathrm{a}} .(.058)$ & \\
\hline $\begin{array}{l}\text { Reward based on } \\
\text { individual performance }\end{array}$ & $-.382^{\mathrm{C}}(.000)$ & & & & & & & & \\
\hline $\begin{array}{l}\text { Information available } \\
\text { enterprise wide }\end{array}$ & & $\left..204^{\mathrm{b}}(.047)\right)$ & & & & $.277^{\mathrm{b}}(.012)$ & & & \\
\hline Information difficult to find & & & & $-.304^{\mathrm{b}}(.003)$ & & $-.244^{\mathrm{a}}(.017)$ & $-.341^{\mathrm{b}}(.001)$ & & \\
\hline Matrix project team & & & & & $.228^{\mathrm{b}}(.026)$ & & & & \\
\hline Partnering is first choice & & & $.225^{\mathrm{b}}(.029)$ & & $.219^{\mathrm{b}}(.033)$ & & & & \\
\hline Partnering is a last resort & & $-.377^{\mathrm{c}}(.000)$ & & & & & & & \\
\hline Alliance benefits our company & & & & & & & $-.286^{\mathrm{c}}(.009)$ & & $-.257^{\mathrm{b}}(.016)$ \\
\hline $\begin{array}{l}\text { Easy for my company } \\
\text { to form temporary alliances }\end{array}$ & & & & $-.240^{\mathrm{b}}(.019)$ & & $-.217^{\mathrm{b}}(.035)$ & $-.249^{\mathrm{b}}(.015)$ & & $-.276^{\mathrm{c}}(.007)$ \\
\hline Supplier involvement in NPD & & & & $.225^{\mathrm{b}}(.042)$ & & $.237^{\mathrm{b}}(.032)$ & $.236^{\mathrm{b}}(.033)$ & $.234^{\mathrm{b}}(.035)$ & $.204^{\mathrm{b}}(.048)$ \\
\hline $\begin{array}{l}\text { Use cross-functional } \\
\text { customer teams }\end{array}$ & & & & $.246^{\mathrm{b}}(.026)$ & & $.245^{\mathrm{b}}(.026)$ & & $.225^{\mathrm{a}}(.042)$ & $.209^{\mathrm{b}}(.042)$ \\
\hline $\begin{array}{l}\text { Alliances due to } \\
\text { difficult operating conditions }\end{array}$ & & & & & $.237^{\mathrm{b}}(.013)$ & & & $.331^{\mathrm{c}}(.002)$ & \\
\hline
\end{tabular}

Significance at

a $10 \%$ level indicated.

b $5 \%$ level indicated.

c $1 \%$ level indicated.

Table 17

Correlations between alliances and competitive objectives.

\begin{tabular}{|c|c|c|c|c|c|}
\hline Variable & Customisation & Cost & Innovation & Speed & Dependability \\
\hline Interaction with competitors & & $-.221^{\mathrm{a}}(.032)$ & & $-.259^{\mathrm{a}}(.011)$ & $-.292^{\mathrm{b}}(.004)$ \\
\hline Customer involvement & $.270^{\mathrm{b}}(.008)$ & & $.292^{\mathrm{b}}(.004)$ & & \\
\hline Exchange core competencies & & & & & $-.245^{\mathrm{a}}(.017)$ \\
\hline Alliances due to difficult operating conditions & & & & $-.232^{\mathrm{a}}(.024)$ & $-.225^{\mathrm{a}}(.028)$ \\
\hline Collaboration with complementary equals & & & $.279^{\mathrm{b}}(.006)$ & & \\
\hline
\end{tabular}

Significance at

a $5 \%$ level indicated.

b $1 \%$ level indicated.

all aspects of business performance. Furthermore, "mastering change and uncertainty" correlates highest with turnover, while "leveraging the impact of people and information" leads to enhanced customer loyalty.

The study also found that "on-time delivery" and "reconfigurable products" (attributes of "enriching the customer") correlate positively with all the performance measures of "enhanced market share", "customer loyalty" and "performance relative to competitors". This thus reemphasizes the diverse nature of the industry, in which both customized and standard products are exchanged. However, it is worth noting that the ability to provide reconfigurable products posted a stronger correlation than ontime delivery. It is also instructive that "providing standard products" also significantly correlates with "enhanced net profit and market share". Accordingly, this result (in which both the contending competitive objectives are at play), points to the diversity of competitive nuclei of members of the oil and gas supply chain, in which some firms supply standard products while others supply more customised products and services.

This study found that where supply chains are considered as long-term partnerships, they lead to enhanced customer loyalty. This could be due to the fact that more time is dedicated to creating the right product to meet the customer requirement, such that customer satisfaction is achieved in the product or service. This customer satisfaction then translates into repeat orders. This finding corroborates an earlier study by Swafford et al. (2006a, 2006b), in which it was found that supplier relations enable improved responsiveness and customer satisfaction.

The result of the analysis also reveals that prosperity in a dynamic business environment can be attainted only through innovation and risk taking. This is evident from the fact that organizations that encourage innovation attain enhanced financial and market-based performance measures. Additionally, where organizations encourage risk taking, by trying new and better solutions, they score high on enhanced market-based business performance measures. Finally, the study also found statistical evidence to support the impact of capturing demand information on both financial and non-financial business performance measures. Additionally, empowerment techniques such as team work and involvement in decision making all impact positively on non-financial measures such as customer loyalty and performance relative to competitors.

This study also tested the relationship between supply chain agility and competitive objectives. Results indicate that the competitive objective of innovation correlates significantly with the agility dimension of "mastering change and uncertainty". Opportunistic cooperation to enhance competitiveness, ability to master change and uncertainty, as well as leveraging the impact of people and information all impact positively on the speed of response (or time-based competition) and innovation. This 
finding corroborates the work of Dubois and Fredriksson (2008). Overall, the study found strong positive correlation between supply chain agility and competitive objectives of proactivity, quality, innovation, delivery and speed. However, only weak correlation was seen between agility and dependability, flexibility and cost reduction.

The practical implications of this study include the fact that it provides some guidance to supply chain managers with respect to the specific relations between the attributes of various dimensions of agility and competitive objectives as well as business performance. For example, in a dynamic business environment (characteristic of the oil and gas industry), cooperation among the industry players could help achieve efficiency and innovation as well as mitigate the effects of costly operations. Hence, considering the relationships among the variables, organizations can achieve higher levels of agility within their supply chain and ultimately higher business performance. This sector-focussed study has provided significant and interesting insights, but more questions arise. For example, the industry is both complex and fragmented. Thus there is the need to undertake further research to broaden the lens of the investigations and look in-depth at each of the stratum of the industry (i.e., operators, contractors and suppliers). This will determine the critical factors that impact and determine the agility of their respective supply sub-chains.

\section{Acknowledgements}

The authors would like to thank the three anonymous reviewers for their extremely constructive and valuable comments, all of which significantly helped to improve the presentation of the paper.

\section{Appendix}

See Appendix Tabels 13-17.

\section{References}

Abdulmalek, F.A., Rajgopal, J., 2007. Analyzing the benefits of lean manufacturing and value stream mapping via simulation: a process sector case study. International Journal of Production Economics 107 (1), 223-236.

Agarwal, A., Shankar, R., Tiwari, M.K., 2006. Modeling the metrics of lean, agile and leagile supply chain: an ANP-based approach. European Journal of Operational Research 173 (1), 211-225.

Ahmed, N.U., Montagno, R.V., Firenze, R.J., 1996. Operations strategy and organizational performance: an empirical study. International Journal of Operations and Production Management 16 (5), 41-53.

Aitken, J., Christopher, M., Towill, D., 2002. Understanding, implementing and exploiting agility and leanness. International Journal of Logistics: Research and Applications 5 (1), 59-74.

Azevedo, S.G., Govindan, K., Carvalho, H., Cruz-Machado, V., 2012. An integrated model to assess the leanness and agility of the automotive industry. Resources, Conservation and Recycling 66, 85-94.

Bal, J., Wilding, R., Gundry, J., 1999. Virtual teaming in the agile supply chain International Journal of Logistics Management 10 (2), 71-82.

Ballou, R.H., Gilbert, S.M., Mukherjee, A., 2000. New managerial challenges from supply chain opportunities. Industrial Marketing Management 29 (1), 7-18.

Bower, D.J., Young, A., 1995. Influences on technology strategy in the UK oil and gas related industry network. Technology Analysis and Strategic Management 7 (4), 407-416.

Braunscheidel, M.J., Suresh, N.C., 2009. The organizational antecedents of a firm's supply chain agility for risk mitigation and response. Journal of Operations Management 27 (2), 119-140.

Breu, K., Hemingway, C.J., Strathern, M., Bridger, D., 2002. Workforce agility: the new employee strategy for the knowledge economy. Journal of Information Technology 17 (1), 21-31.

Browne, J., Sackett, P.J., Wortmann, J.C., 1995. Future manufacturing systems: towards the extended enterprise. Computers in Industry 25 (3), 235-254.

Browne, J., Zhang, J., 1999. Extended and virtual enterprises: similarities and differences. International Journal of Agile Management Systems 1 (1), 30-36.

Burgess, T., 1994. Making the leap to agility: defining and achieving agile manufacturing through business process redesign and business network redesign. International Journal of Operations and Production Management 14 (11), 23-34.

Christopher, M., 2000. The agile supply chain: competing in volatile markets. Industrial Marketing Management 29 (1), 37-44.

Christopher, M., 2005. Logistics and Supply Chain Management: Creating Valueadded Networks. FT Prentice Hall, Harlow.

Costantino, N., Dotoli, M., Falagario, M., Fanti, M.P., Mangini, A.M., 2012. A mode for supply management of agile manufacturing supply chains. Internationa Journal of Production Economics 135 (1), 451-457.

Crabtree, E.A., Bower, D.J., Keogh, W., 2000. Manufacturing strategies of small technology-based firms in the UK oil industry. International Journal of Manufacturing Technology and Management 1 (4/5), 455-463.

Crabtree, E., Bower, D.J., Keogh, W., 1997. Conflict or collaboration: the changing nature of inter-frim relationships in the UK oil and gas industry. Technology Analysis and Strategic Management 9 (2), 179-191.

CRINE Network, 1999. Supply Chain Management in the UK Oil and Gas Sector. CRINE Network and Ernst and Young, London.

Cumbers, A., MacKinnon, D., 2004. Introduction: clusters in urban and regional development. Urban Studies 41 (5/6), 959-969.

Cumbers, A., Mackinnon, D., Chapman, K., 2003. Innovation, collaboration, and learning in regional clusters: a study of SMEs in the Aberdeen oil complex. Environment and Planning 35 (9), 1689-1706.

Dubois, A., Fredriksson, P., 2008. Cooperating and competing in supply networks: making sense of a triadic strategy. Journal of Purchasing and Supply Management 14 (3), 170-179.

Ernst, D., Steinhubl, A.M.J., 1997. Alliances in upstream oil and gas. McKinsey Quarterly No 2, 144-155.

Finch, J.H., 2002. Transferring exploration and production activities within the UK's upstream oil and gas industry: a capabilities perspective. Journal of Evolutionary Economics 12 (1/2), 55-81.

Forza, C., 2002. Survey research in operations management: a process-based perspective. International Journal of Operations and Production Management 22 (2), 152-194.

Gehani, R.R., 1995. Time-based management of technology: a taxonomic integration of tactical and strategic roles'. International Journal of Operations and Production Management 15 (2), 19-35.

Gharajedaghi, J., 2005. Systems Thinking: Managing Chaos and Complexity: A Platform for Designing Business Architecture. Butterworth-Heinemann.

Gill, J., Johnson, P., 2002. Research Methods for Managers. Sage, London.

Gligor, D.M., Holcomb, M.C., 2012. Understanding the role of logistics capabilities in achieving supply chain agility: a systematic literature review. Supply Chain Management: An International Journal 17 (4), 438-453.

Goldman, S.L., Nagel, R.N., Preiss, K., 1995. Agile Competitors and Virtual Organizations: Strategies for Enriching the Customer. Van Nostrand Reinhold, New York.

Goranson, H.T., 1999. The Agile Virtual Enterprise: Cases, Metrics. Tools. Quorum.

Gosling, J., Purvis, L., Naim, M.M., 2010. Supply chain flexibility as a determinant of supplier selection. International Journal of Production Economics 128 (1), 11-21.

Grandori, A., Soda, G., 1995. Inter-firm networks: antecedents, mechanisms and forms. Organization Studies 16 (2), 183-214.

Gunasekaran, A., Ngai, E.W.T, 2012. The future of operations management: an outlook and analysis. International Journal of Production Economics 135 (2) 687-701.

Hair, J.F.J., Black, W.C., Babin, B.J., Anderson, R.E., Tatham, R.L., 2006. Multivariate Data Analysis. Prentice Hall, Upper Saddle River, New Jersey, Pearson.

Harland, C.M., 1996. Supply chain management: relationships, chains and networks. British Journal of Management 7 (S1), S63-S80.

Hill, T., 2000. Operations Management: Strategic Context and Managerial Analysis. Palgrave, Chippenham, Wiltshire.

Jagdev, H.S., Browne, J., 1998. The extended enterprise: a context for manufacturing. Production Planning and Control 9 (3), 216-229.

Jain, V., Benyoucef, L., Deshmukh, S.G., 2008. A new approach for evaluating agility in supply chains using fuzzy association rules mining. Engineering Applications of Artificial Intelligence 21 (3), 367-385.

Kidd, P.T., 1994. Agile Manufacturing: Forging New Frontiers. Addison-Wesley, Wokingham, England.

Kisperska-Moron, D., de Haan, J., 2011. Improving supply chain performance to satisfy final customers: leagile experiences of a Polish distributor. International Journal of Production Economics 133 (1), 127-134.

Khan, K.A., Pillania, R.K., 2008. Strategic sourcing for supply chain agility and firms' performance: a study of Indian manufacturing sector. Management Decision 46 (10), 1508-1530.

Kumar, A., Motwani, J., 1995. A methodology for assessing time-based competitive advantage of manufacturing firms. International Journal of Operations and Production Management 15 (2), 36-53.

Lambert, D.M., Cooper, M.C., 2000. Issues in supply chain management. Industria Marketing Management 29 (1), 65-83.

Lamming, R., 1996. Squaring lean supply with supply chain management. International Journal of Operations and Production Management 16 (2), 183-196.

Lamming, R., Johnsen, T., Zheng, J., Harland, C., 2000. An initial classification of supply networks. International Journal of Operations and Production Management 20 (6), 675-691.

Lin, C.-T., Chiu, H., Chu, P.-Y., 2006. Agility index in the supply chain. Internationa Journal of Production Economics 100 (2), 285-299. 
Loasby, B.J., 1998. The organisation of capabilities. Journal of Economic Behaviour and Organization 35 (2), 139-160.

Mackinnon, D., Chapman, K., Cumbers, A., 2004. Networking, trust and embeddedness amongst SMEs in the Aberdeen oil complex. Entrepreneurship and Regional Development: An International Journal 16 (2), 87-106.

Mason-Jones, R., Naylor, B., Towill, D.R., 2000. Engineering the leagile supply chain. International Journal of Agile Management Systems 2 (1), 54-61.

Mason-Jones, R., Towill, D.R., 1997. Information enrichment: designing the supply chain for competitive advantage. Supply Chain Management 2 (4), 137-148.

Mason-Jones, R., Towill, D.T., 1999. Total cycle time compression and the agile supply chain. International Journal of Production Economics 62 (1/2), 61-73.

Michael, R.K., Wempe, W.F., 2002. Further evidence on the extent and origins of JIT's profitability effects. Accounting Review 77 (1), 203-225.

Mike, D., Venu, N., Florian, W., 2012. Agile operations for volatile times. McKinsey Quarterly 3, 126-131, May.

Miles, R.E., Snow, C.C., 1987. Network organisations: new concepts for new forms. California Management Review 28 (3), 62-73.

Miles, R.E., Snow, C.C., 1992. Causes of failure in network organizations. California Management Review 34 (4), 53-72.

Naim, M.M., Gosling, J., 2011. On leanness, agility and leagile supply chains. International Journal of Production Economics 131 (1), 342-354.

Ngai, E.W.T., To, C.K.M., Ching, V.S.M., Chan, L.K., Lee, M.C.M., Choi, Y.S., Chai, P.Y.F., 2012. Development of the conceptual model of energy and utility management in textile processing: a soft systems approach. International Journal of Production Economics 135 (2), 607-617.

Pihkala, T., Varamaki, E., Vesalainen, J., 1999. Virtual organization and the SMEs: a review and model development. Entrepreneurship and Regional Development 11 (4), 335-349.

Porter, M.E., 1990. The Competitive Advantage of Nations. Macmillan Press Limited, London.

Porter, M.E., 1998. Clusters and the new economics of competition. Harvard Business Review 76 (6), 77-90.

Porter, M.E., 2003. The economic performance of regions. Regional Studies 36 (6/7), 549-578.

Prahalad, C.K., Hamel, G., 1990. The core competence of the corporation. Harvard Business Review 68 (3), 79-91.

Prajogo, D.I., Sohal, A.S., 2006. The relationship between organization strategy, total quality management (TQM), and organization performance-the mediating role of TQM. European Journal of Operational Research 168 (1), 35-50.

Ramdas, K., Spekman, R.E., 2000. Chain or shackles: understanding what drives supply-chain performance. Interfaces 30 (4), 3-21.

Ramstad, L.S, Halvorsen, K., Marintek, A.M., 2010. Improved coordination with integrated planning: organisational capabilities. SPE Intelligent Energy Conference and Exhibition, Society of Petroleum Engineers, 23-25 March, Utrecht, The Netherlands.

Reichhart, A., Holweg, M., 2008. Co-located supplier clusters: forms, functions and theoretical perspectives. International Journal of Operations and Production Management 28 (1), 53-78.

Richardson, G.B., 1972. The organisation of industry. The Economic Journal 82 (327), 883-896.

Robertson, M., Jones, C., 1999. Application of lean production and agile manufacturing concepts in a telecommunications environment. International Journal of Agile Management Systems 1 (1), 14-16.

Romano, P., 2000. Impact of supply chain sensitivity to quality certification on quality management practices and performances. Total Quality Managemen 13 (7), 981-1000.

Sarkis, J., Zhu, Q., Lai, K.-H., 2011. An organizational theoretic review of green supply chain. International Journal of Production Economics 130 (1), 1-15.

Skyttner, L., 2006. General Systems Theory: Problems, Perspective, Practice. World Scientific Publishing Company.
Spekman, R.E., Kamauff, J.W., Myhr, N., 1998. An empirical investigation into supply chain management: a perspective on partnerships. International Journal of Physical Distribution and Logistics Management 28 (8), 630-650.

Swafford, P.M., Ghosh, S., Murthy, N., 2006a. The antecedents of supply chain agility of a firm: scale development and model testing. Journal of Operations Management 24 (2), 170-188.

Swafford, P.M., Ghosh, S., Murthy, N., 2006b. A framework for assessing value chain agility. International Journal of Operations and Production Management 26 (2), 118-140.

Swafford, P.M., Ghosh, S., Murthy, N., 2008. Achieving supply chain agility through IT integration and flexibility. International Journal of Production Economics 116 (2), 288-297.

Tabachnick, B.G., Fidell, L.S., 2007. Using Multivariate Statistics. Pearson International Edition, Boston.

Tolone, W.J., 2000. Virtual situation rooms: connecting people across enterprises for supply-chain agility. Computer-Aided Design 32 (2), 109-117.

van der Vaart, T., van Donk, D.P., 2008. A critical review of survey-based research in supply chain integration. International Journal of Production Economics 111 (1), 42-55.

van Hoek, R.I., 2000. The thesis of leagility revisited. International Journal of Agile Management Systems 2 (3), 196-201.

van Hoek, R.I., 2001. Moving forward with agility. International Journal of Physical Distribution and Logistics Management 31 (4), 290-300.

van Hoek, R.I., Harrison, A., Christopher, M., 2001. Measuring agile capabilities in the supply chain. International Journal of Operations and Production Management $21(1 / 2), 126-147$.

Vastag, G., Kasarda, J.D., Boone, T., 1994. Logistical support for manufacturing agility in global markets. International Journal of Operations and Production Management 14 (11), 73-85.

Whitten, G.D., Green, K.W., Zelbst, P.J., 2012. Triple-A supply chain performance. International Journal of Operations and Production Management 32 (1), $28-48$.

Wisner, J.D., 2003. A structural equation model of supply chain management strategies and firm performance. Journal of Business Logistics 24 (1), 1-26.

Xia, Y., Tang, T.L.-P., 2011. Sustainability in supply chain management: suggestions for the auto industry. Management Decision 49 (4), 495-512.

Youssef, M.A., 1994. The impact of the intensity level of computer-based technologies on quality. International Journal of Operations and Production Management 14 (4), 4-25.

Yusuf, Y.Y., Adeleye, E.O., 2002. A comparative study of lean and agile manufacturing with a related survey of current practices in the UK. International Journal of Production Research 40 (17), 4545-4562.

Yusuf, Y.Y., Adeleye, E.O., Sivayoganathan, K., 2003. Volume flexibility: the agile manufacturing conundrum. Management Decision 41 (7), 613-624.

Yusuf, Y.Y., Gunasekaran, A., Adeleye, E.O., Sivayoganathan, K., 2004. Agile supply chain capabilities: determinants of competitive objectives. European Journal of Operational Research 159 (2), 379-392.

Yusuf, Y.Y., Sarhadi, M., Gunasekaran, A., 1999. Agile manufacturing: the drivers, concepts and attributes. International Journal of Production Economics $62(1 / 2)$, 33-43.

Zhou, Y.C., Wang, X.N., Liu, X.P., Xue, L., Liang, S., Sun, C.H., 2010a. Enabling integrated information framework as cloud services for chemical and petroleum industry. IEEE 6th World Congress on Services, Miami, Florida, USA, July, $5-10$.

Zhou, Y.C., Liu, X.P., Wang, X.N., Xue, L., Liang, X.X., Liang, S., 2010b. Business process centric platform-as-a-service model and technologies for cloud enabled industry solutions. IEEE 3rd International Conference on Cloud Computing (CLOUD), Miami, Florida, USA, July, 5-10. 